\title{
Çocuk Gelişimi Programı Öğrencilerinin Okul Öncesi Dönem Çocuklarına Yönelik STEM Temelli Hazırlanan Etkinlikler ile İlgili Görüşleri
}

\author{
Merve ŞAHIN \\ Çanakkale Onsekiz Mart Üniversitesi \\ mervesahin0617@gmail.com \\ ORCID ID: 0000-0001-9394-9511
}

\begin{tabular}{lrr} 
Araştırma Makalesi & DOI: $10.31592 /$ aeusbed.910255 \\
\hline Geliş Tarihi: 05.04.2021 & Revize Tarihi: 14.06 .2021 & Kabul Tarihi: 14.06 .2021
\end{tabular}

\section{Atıf Bilgisi}

Şahin, M. (2021). Çocuk gelişimi programı öğrencilerinin okul öncesi dönem çocuklarına yönelik stem temelli hazırlanan etkinlikler ile ilgili görüşleri. Ahi Evran Üniversitesi Sosyal Bilimler Enstitüsü Dergisi, 7(2), 518-536.

\section{ÖZ}

$\mathrm{Bu}$ çalışma, Çocuk Gelişimi Programı öğrencilerinin okul öncesi çocuklara yönelik STEM temelli etkinliklerin uygulanmasına iliş̧in görüşlerini incelemeyi amaçlamaktadır. Bu amaçla nitel araştırma yöntemlerinden biri olan fenomenolojik araştırma deseni kullanılmıştır. Araştırmanın örneklemini, Marmara Bölgesinde bulunan bir devlet üniversitesinin Çocuk Gelişimi programında öğrenim gören 2. Sınıf öğrencileri oluşturmaktadır. Veriler, 2020-2021 akademik yılı güz döneminde toplanmıştır. Öğrencilerin STEM temelli etkinliklere ilişkin görüşlerini öğrenmek için haberle anlatın 7 görüşme sorusu kullanılmıştır. Görüşmede elde edilen içerik analiz ile analiz edilmiştir. Görüşme sorularının geçerlik ve güvenirliği yapılmıştır. Araştırmada elde edilen bulgularda, öğrencilerin öğrenmeye yönelik STEM etkinliklerini planlamada zorluk yaşadıklarını, ancak ilgili alan bilgisine sahip olduktan sonra kendilerini yeterli hissettiklerini ve uygulamada herhangi bir güçlük yaşamadıklarını belirtmişlerdir. Ayrıca günlük yaşam, bilim, teknoloji, fen ve matematiğe cevabın önemli bir yer tuttuğu eğitimde STEM etkinliklerinin önemli bir yere sahip olduğu görülmektedir. Daha önce bilmedikleri için okul öncesi dönem çocuklarına yönelik staj uygulamalarında STEM etkinliklerini kullanmadıklarını ve daha sonraki uygulamalarında STEM'i kullanmaya istekli olduklarını söylüyorlar. Bu bulgular ışı̆̆ında bilim, teknoloji, mühendislik ve matematik alanlarının önemli olduğu ve STEM eğitiminde erken yaşlardan itibaren öğretimin gerekli olduğu belirtilmektedir. Beceri sahibi bireyler yetiştirmek için STEM temelli bir yapı yapılması gerektiğine inandıkları anlaşılmaktadır. Öğrencilerin günlük yaşamla ilgili olayları açıklamada STEM etkinliklerinin gerekliliğine inandıkları görülmektedir.

Anahtar Kelimeler: Çocuk gelişimi, okul öncesi STEM etkinlikleri, okul öncesi eğitim.

\section{Views of Child Development Program Students on STEM-Based Activities for Preschool Children}

\begin{abstract}
This study aims to examine the views of Child Development Program students about the implementation of STEM-based activities for preschool children. For this purpose, phenomenological research design, which is one of the qualitative research methods, was used. The sample of the research consists of 2nd year students studying in the Child Development program of a state university in the Marmara Region. The date has been collected in the 2020-2021 academic year fall semester. In order to learn the students' views on STEM-based activities, tell with the news 7 interview questions were used. The content obtained in the interview was analyzed with the analysis. The validity and reliability of the interview questions were made. In the findings obtained in the study, they stated that they experienced difficulties in planning STEM activities for learning a child development program, but they felt sufficient after having the relevant field knowledge and did not have any difficulties in implementation. In addition, it is seen that STEM activities have an important place in education, where the answer to everyday life, science, technology, science and mathematics has an important place. They say that they did not use STEM activities in internship practices for preschool children before because they did not know, and they are willing to use STEM in their later applications. In the light of these findings, it is stated that science, technology, engineering and mathematics fields are important and teaching is necessary in STEM education from an early age. It is understood that they have the belief that a STEMbased structure should be made to raise individuals with skills. It is seen that students believe in the necessity of STEM activities in explaining the events related to daily life.
\end{abstract}

Keywords: Child development, STEM activities in early childhood period, pre-school education.

\section{Giriş}

Bilim, Teknoloji, Mühendislik ve Matematik (Science, Technology, Engineering and Math [STEM]) alanlarının bütünleştirilmesinden oluşan STEM'in eğitimde terim veya kavram olarak 
kullanılması ilk olarak 2001 yılında The National Science Foundation yöneticisi Judith A. Ramaley tarafından ifade edilmiş ve kısa sürede yayılmıştır (Yıldırım ve Altun, 2014). STEM eğitim yaklaşımı, Fen ve Matematik, Teknoloji ve Matematik alanları arasına köprüler kuran, disiplerarası entegrasyonu sağlayan bütüncül bir çalışma alanıdır disiplinlerinin de entegre edilmesini içeren bütüncül bir yaklaşımdır (Bybee, 2010, Meng, Idris ve Eu, 2014). STEM eğitimi öğrencilerin karşılaştıkları herhangi bir problem karşısında kendi bilgilerini ve anlam üretme süreçlerini işe koşarak, problemi anlama, çözüm üretme becerileri geliştirerek kalıcı öğrenme gerçekleştirmenin yanında 21. yy. becerileri olarak nitelendirilen, araştırma, sorgulama, ,eleştiri, analiz-sentez yapma, problem çözme becerisi kazanma, disiplinler arası işbirliği yapma, okul, toplum, iş arasında bağlantı kurarak, iletişim becerileri yüksek, sorumluluk alma, değişikliklere adapte olabilme, sosyal ve kültürel etkileşim içinde olma, bilgi, iletişim ve teknoloji becerilerini kazanma, yaşam becerileri geliştirme, liderlik özelliklerine sahip olma ve küresel girișimcilik gibi alanlarda katkı sağlayarak aktif olmalarını sağlaması nedeniyle önemlidir (Günüç, Odabaşı ve Kuzu, 2013; Korkmaz ve Buyruk, 2016; Partnership for 21 st Century Skills, 2009; Tezel ve Yaman, 2017;Thomas, 2014;Wang, 2012). STEM eğitimin amacı akademik disiplinleri, gerçek hayatla ilişkilendirerek öğrencilerin disiplinler arası bağlantı kurarak sahip oldukları bilgi ve becerileri okul, toplum ve iş girişimlerinde yaratıcı ve gerçekçi şekilde kullanabilecek bireyler yetiştirmektir (Rogers ve Porstmore, 2004; Sanders, 2009). Uygulama sürecinde etkili bir STEM eğitimi gerçekleştirmek için, öğrencilerin ilgi ve deneyimlerini ön planda tutmak önemlidir, bu şekilde öğrencilerin katılımı ve ilgileri sağlanabilir (National Research Council, 2011). STEM eğitim yaklaşımın esası proje tabanlı öğrenme yaklaşımıdır. Bu yaklaşım sayesinde öğrenciler karşılaştıkları problem ve güçlükleri tüm disiplinleri bir arada kullanarak yeni bir ürün oluşturabilirler ve bu sayede süreçte kendi öğrenmelerini gerçekleştirerek, zevkli bir şekilde problemlere çözüm yolu bularak, hedeflerini elde ederler (Nesbitt, 2013).

Okul öncesi dönem çocukları araştıran, sorgulayan, gündelik hayatta karşılaştıkları durumlarla ilgili sürekli sorular soran, olayların neden ve sonuçları arasında bağlantı kurmaya çalışan, meraklı, güçlü bir hayal gücüne sahip oldukları bu dönemde STEM eğitimine başlanması gerekmektedir (Aktaş Arnas, 2002; Küçükturan, 2005; National Science Teacher Association ,2014). Yapılan birçok araştırma da erken dönemde STEM deneyimlerine sahip olmanın, ilerleyen dönemlerde karmaşı problemlere, yeni fikirler üretme, ekonomik anlamda gelişmelere de yarar sağlayacak bireylerin yetiştirilmesinde önemli bir rolü olacağını ifade etmektedir (Aronin ve Floyd,2013; Chesloff, 2013; DeJarnette, 2012). 2013 y1lında güncellenen Okul Öncesi Eğitim Programı incelendiğinde, fen ve matematik etkinliğini de içine alan, tamamen öğretmenin bilgi ve yaratıcılığına dayanacak, öğrencilere rehberlik yaparak hazırlanacak materyallerle STEM eğitimini çeşitli etkinlikler ile yapabileceği görülmektedir (Millî Eğitim Bakanlığı, 2013). Tüm bunlar göz önüne alındığında STEM'in kalbindeki kavramlar olan merak, yaratıcılık, STEM eğitimine en uygun zaman olarak okul öncesi dönemdir (Allen, 2016; Chesloff, 2013; Torres Crospe, Kraatz ve Pallansch, 2014).

Araştırmacılar, okul öncesi dönemde çocuklar için hazırlanacak STEM programında bilgiyi özümseme, beceriler, yeniden düzenleme eğilimleri ve duygular olarak dört ana hedefte belirtmektedir (Moomaw, 2013). Böylesine önemli bir dönemde çocuklarla birlikte öğrenme ortamlarında yer alacak kişilerin de STEM eğitimi konusunda ön koşul bilgilere sahip olmaları gerekmektedir. Bunun yanında STEM eğitimi ile ilgili olumlu düşüncelere sahip olmaları beklenmektedir. Bireyin bir davranışa karşı olumlu tutumu var ise o davranışı gösterme olasılığa yüksek olacaktır (Fishbein ve Ajzen, 1975; Turan, 2011). Küresel dünyada hızla değişen eğitim programlarında STEM konusunda donanımlı öğretmenler yetiştirmeye çaba gösterilmektedir (Teo ve Ke, 2014). Araştırmanın yürütüldüğü Çocuk Gelişimi programı öğrencilerinin ileride okul öncesi dönem çocukları ile çalışacakları düşünüldüğünde bu alanda yeterli donanıma sahip olmaları gerektiği anlaşılmaktadır.

Alan yazın incelendiğinde önlisans çocuk gelişimi programında yapılan bir çalışmaya rastlanmamıştır. Ancak bu alanda yetişen öğrencilerin staj yaptığı, mezun olduktan sonra özel kreşler, gündüz bakımevlerinde öğretmen ve yardımcı öğretmen olarak çalıştıkları göz önüne alındığında bu alanda bir eksiklik olduğu görülmektedir. Yapılan çalışmalar genellikle lisans programlarında öğretmen adayları ile gerçekleştirilmiştir. Önlisans programında STEM etkinlikleri ile ilgili benzer bir çalışmaya rastlanmamıştır. Nadelson, Seifert, Moll ve Coats (2012), içerik bilgisi, konu alan bilgisine 
sahip olan öğretmen adaylarının öğretim etkinlikleri sırasında rahat oldukları ve STEM alanlarına karşı olumlu tutumlarının, STEM öğretimi için öz yeterlik algılarını pozitif anlamda etkilerken öte yandan sorgulayıcı bir anlayış kullanmalarını olumlu yönde etkilediği ifade etmiştir.

Marulcu ve Sungur'a (2012) göre, öğretmenlerin lisans eğitim programlarında ve görevde oldukları süre içerisinde aldıkları hizmet içi eğitim programlarında da STEM uygulamalarına yeteri kadar önem verilmediği görülmektedir. Her ne kadar son yıllarda STEM eğitiminin yansımalarını ait çalışmaların sayısı hızla artmış olsa da, STEM eğitiminin ne olduğu, öğretim programındaki yeri ve sınıf ortamında ne şekilde kullanılacağı ile ilgili net bir görüş birliğine sahip olunamadığı, yapılan çalışmalarda fen ve matematiğin birlikte kullanıldığ 1 , mühendislik alanına ait uygulamalar ve kodlamanın ön planda olduğu görülmektedir(Çepni, 2018). Çınar, Pırasa, Uzun ve Erenler (2016), STEM modelinin öğrencileri bireysel ve sosyal alanlarda geliştirdiği ve öğrencilerin bu STEM etkinliklerini kendi sınıflarında uygulamak istediklerini ifade etmişlerdir. Okul öncesi öğretmenleri ve öğretmen adayları ile yürütülen bir diğer çalışmada, katılımcıların STEM eğitimi ile ilgili olumlu bir düşünce içerisinde oldukları ve STEM eğitiminin çocukların gelişimine katkı sağlayacağı şeklinde görüşler belirttikleri görülmüştür (Uğraş, 2017; Uğraş ve Genç, 2018). Yıldırım ve Türk'ün (2018) yaptığ1 farklı bir çalışmada ise, öğretmen adayların STEM temelli eğitim almalarının, öğrencilerin STEM eğitimine dair tutumlarını gelişimesinde önemli bir etki sağladığı sonucuna ulaşılmıştır. Yıldırım ve Selvi'nin (2015) yaptı̆̆ çalışmada, öğretmen adayları STEM eğitimi hakkında olumlu bir tutum gösterseler de STEM eğitiminin az sayıda öğrenci ile gerçekleştirilmediği durumlarda korku duygusu taşıdıkları görülmüştür. STEM eğitimine karşı olumlu bir bakış açısına sahip olsalar da STEM eğitimini kalabalık sınıflarda uygulamaya yönelik olumsuz tutum ve korku duygusu taşıdıkları sonucuna ulaşmıştır. Burada olumlu bir bakış açısına sahip olmanın, her zaman uygulamayı olumlu yönde etkileyeceği düşünülmeden diğer değişkenlerinde ele alınması gerektiği görülmektedir.Bu çalışmaların aksine Hacıömeroğlu ve Bulut (2016) yaptıkları çalışmada, öğretmenlerin hem STEM etkinliklerine karşı olumlu bir yönde bir yaklaşım içerisinde oldukların hem de STEM'in bütünleşik şekilde kullanılmasına yönelik olumlu yaklaşım gösterdiklerini belirtmiştir. Darling-Hammond ve Bransford (2005), ders içeriği olarak fen ve matematikle ilgili temel bilgilere sahip olan öğretmen adaylarının bu bilgileri öğretmeyi daha kolay bir şekilde yaptıklarını ortaya ortaya koymuştur.

$\mathrm{Bu}$ çalışma ile Çocuk Gelişimi Programı öğrencilerinin STEM temelli etkinlikler ile ilgili görüşleri ortaya koyulmak amaçlanmıştır. Öğrencilerle yapılan uygulamalar sonucunda birebir görüşmeler yapılarak gerçek düşünce, fikir ve duygularıyla ilgili derinlemesine bilgi elde edilmesi hedeflenmiştir. Çocuk gelişimi programındaki öğrenciler mezun olduktan sonra okul öncesi dönemdeki çocuklarla çalışacakları için STEM etkinlikleri hakkında görüşlerinin ortaya konulması önemlidir. Bu konuyla ilgili çocuk gelişimi öğrencileriyle yapılmış bir çalışmaya rastlanmamıştır. $\mathrm{Bu}$ özelliği ile alana katkı sağlayacağı düşünülmektedir.

$\mathrm{Bu}$ çalışmanın amacı, çocuk gelişimi programı öğrencilerinin STEM etkinliklerini uyguladıktan sonra STEM etkinliklerine yönelik görüşlerinin incelenmesidir. Çalışmada yapılan uygulamaların öğrencilerin düşünceleri üzerinde bir değişikliğe yol açıp açmadığ 1 açıklanmaya çalışılmıştır. Bu doğrultuda aşağıdaki sorulara yanıt aranmaktadır:

1. Çocuk gelişimi programı öğrencilerinin STEM etkinlikleri planlamasında zorlandıkları konular nelerdir?

2. Öğrencilerin uygulamalardan sonra STEM etkinlikleri planlamada kendilerini yeterli görmekte midir?

3. Öğrenciler STEM etkinliklerini uyguladıktan sonra bilim, teknoloji, mühendislik ve matematiğe yönelik görüşlerinde bir değişim var mıdır?

4. Öğrencilerin STEM etkinlikleri uyguladıktan önce ve uyguladıktan sonra okul öncesi dönemdeki çocuklara yönelik staj uygulamalarında bu etkinliklere yer verme hakkında görüşleri nelerdir?

5. Öğrenciler, gündelik yaşamla ilgili olayları açıklamada STEM etkinliklerinin yararlı olduğunu düşünmekte midir?

6. Öğrencilerin, STEM etkinliklerini planlama ve uygulamalardan sonra uygulayıcı ve öğrencilere önerileri nelerdir? 


\section{Yöntem}

\section{Araştırma Modeli}

$\mathrm{Bu}$ çalışma fenomenolojik desen ile gerçekleştirilmiştir. Katılımcıların yaşamış oldukları deneyim ile ilgili hissettikleri, algıları, düşünceleri ve bunları nasıl yapılandırıp kendilerinde nasıl bir bilinçlilik durumu oluşturduğu fenomenoloji çalışmalarında masaya yatırılır (Van Manen, 2007). Çalışmada, Çocuk Gelişimi Programı öğrencilerinin Çocukta Bilim ve Teknoloji dersi kapsamında STEM temelli etkinlikleri uyguladıktan sonra bu etkinlikler ile ilgili düşüncelerini ortaya konulmaktadır. STEM etkinlikleri ile ilgili düşüncelerini derinlemesine bir şekilde ortaya koymak amacıyla nitel araştırma yöntemlerinden görüşme yöntemi kullanılmış olup, yarı yapılandırılmış görüşme soruları ile veriler toplanmıştır. Görüşme türlerinden yarı yapılandırılmış görüşmede, görüşmelerde kullanılmak üzere hazırlanan sorular ile görüşülen kişilerin sorulara istedikleri uzunlukta cevap vermesi araştırmacıya verilen cevapların ötesinde derinlemesine bilgi almasını sağlar (Creswell, 2009, Karasar, 2016).

\section{Çalışma Grubu}

Çalışma grubunda, Marmara Bölgesinde bulunan bir devlet üniversitesinin Çocuk Gelişimi programı 2. sınıfta öğrenim gören, yaşları 18-22 arasında değişen 27 kız ve 1 erkek öğrenciden oluşan 28 öğrenci bulunmaktadır. Çalışma grubunda yer alan öğrenciler amaçlı örnekleme yöntemi ile belirlenmiştir.

\section{Veri Toplama Aracı}

Veri toplama aracı olarak araştırmacı tarafindan oluşturulan 7 soruluk yarı yapılandırılmış görüşme formu kullanılmıştır. Çocukta Bilim ve Teknoloji dersi kapsamında 10 hafta boyunca öğrencilerle birlikte STEM etkinlikleri planlanarak uygulanmıştır. Tüm bu uygulamalar sonucunda öğrenciler ile yüz yüze gerçekleştirilen görüşmeler ile derinlemesine bilgi alınmaya çalışılmıştır. Görüşmeler 30-35 dakika aras1 sürmüştür. Öğrencilerin isimleri yerine Ö1,Ö2,Ö3,..,Ö28 şeklinde kodlama yapılmıştır.

\section{Verilerin Toplanması ve Analizi}

STEM hakkında bilgiler öğrencilerle paylaşıldıktan ve STEM etkinlik planları öğrencilerler hazırlanıp, uygulandıktan sonra yarı yapılandırılmış görüşme soruları ile toplanan veriler içerik analizi kullanılarak analiz edilmiştir. İçerik analizi, nitel verilerin sistematik bir şekilde ortaya koyulmasıdır (Schreier, 2014). Yapılan görüşmeler, yazıya aktarıldıktan sonra, araştırmacı ve bir uzman tarafindan görüşme sorularına verilen cevaplara içerik analizi yapılmıştır. Araştırmacı ve bir uzmanın "ortak görüş" ve "görüş farklılığı" şeklinde ifade edilmektedir. Bu çalışmada, içerik analizinde uyuşum yüzdesi formülü olan "güvenirlik = ortak görüş/(ortak görüş + görüş farklılığı) x 100" kullanılmıştır (Miles ve Huberman, 1994, p.64). Çalışmada, uyuşum yüzdesi 0,88 olarak bulunmuştur. Elde edilen değer \% 70' in üstünde olduğundan dolayı çalışmaya ait içerik analizinin güvenilir olduğu sonucuna varılmıştır (Yıldırım ve Şimşek, 2003).

Yarı yapılandırılmış görüşme formu hazırlanırken, öncelikli olarak alan-yazın taraması yapılarak araştırmacı tarafından 7 soruluk görüşme formu oluşturulmuştur. Görüşme formunda yer alan sorular okul öncesi eğitim alanında uzman iki öğretim üyesi ve bir ölçme değerlendirme uzmanından soruların kapsamı, açık ve anlaşılır olması ile ilgili değerlendirmeleri alınmıştır. Uzman görüşlerinden elde edilen veriler doğrultusunda görüşme sorularına son hali verilmiştir. Çalışmanın geçerliğini ve güvenirliğini sağlamada aşağıdaki (Tablo 1.) önlemler alınmıştır 
Tablo 1

Geçerlik ve Güvenirlik Çalı̧̧maları

\begin{tabular}{|c|c|c|}
\hline \multirow[t]{3}{*}{ Geçerlik } & \multirow[t]{2}{*}{ İç geçerlik } & Uzman görüşünün alınması \\
\hline & & $\begin{array}{l}\text { Katılımcıların onayının } \\
\text { alınması }\end{array}$ \\
\hline & \multirow[t]{4}{*}{ Dış geçerlik } & $\begin{array}{ll}\text { Veri toplama } & \text { araci ve } \\
\text { uygulama } & \text { sürecinin } \\
\text { açılanması } & \end{array}$ \\
\hline & & $\begin{array}{l}\text { Veri analiz sürecinin } \\
\text { açıklanması }\end{array}$ \\
\hline & & $\begin{array}{l}\text { Çalışma grubunun seçim } \\
\text { şeklinin açıklanması }\end{array}$ \\
\hline & & Amaçlı örnekleme yapılması \\
\hline \multirow[t]{3}{*}{ Güvenirlik } & İç güvenirlik & $\begin{array}{l}\text { Tüm söylenenlerin not alınarak } \\
\text { veri kaybının önlenmesi }\end{array}$ \\
\hline & & $\begin{array}{l}\text { Görüşme formundan doğrudan } \\
\text { alıntılar yapılması }\end{array}$ \\
\hline & Diş güvenirlik & $\begin{array}{l}\text { Verilerin objektif şekilde } \\
\text { tartışılması }\end{array}$ \\
\hline
\end{tabular}

\section{Araştırma Etiği}

Yapılan bu çalışmada Çanakkale Onsekiz Mart Üniversitesi Lisansüstü Eğitim Enstitüsü Etik Kurulu'ndan 11.03.2021 tarih ve 05/12 sayılı kararı, E-84026528-050.01.04-2100041458 say1 numaralı gerekli izinler alınmıştır.

\section{Bulgular}

Çalışmada problem olarak ele alınan, "Çocuk Gelişimi Programı Öğrencilerinin STEM etkinliklerini uyguladıktan sonra sahip oldukları görüşlerinin" incelendiği bu bölümde çocuk gelişimi programı öğrencileri ile gerçekleştirilmiştir.

Öğrencilerin STEM etkinlik uygulamalarına yönelik gerçekleştirilen görüşmeler sonucunda elde edilen veriler analiz edilerek araştırma sorularına ilişkin temalar, kategoriler oluşturulmuştur.

Tablo 2

Öğrencilerin STEM Temelli Etkinlikler Planlarken Hangi Aşamalarda Zorlandığını İlişkin Görüşleri

\begin{tabular}{|c|c|c|c|}
\hline Temalar & Alt Temalar & f & Kodlar \\
\hline \multirow[t]{9}{*}{$\begin{array}{l}\text { Planlama } \\
\text { aşaması }\end{array}$} & $\begin{array}{l}\text { STEM eğitimi hakkında yeterli bilgiye sahip } \\
\text { olmama }\end{array}$ & 16 & $\begin{array}{l}\text { Ö1,2,4,5,6,8,9,10,13,15,18,19, } \\
21,22,25,26,28\end{array}$ \\
\hline & Disiplinler arasında ilişki kuramama & 16 & $\begin{array}{l}\text { Ö1,2,4,6,8,9,14,18,19,21,22,23, } \\
24,25,28,29\end{array}$ \\
\hline & $\begin{array}{l}\text { Yaş grubuna ve gelişimine uygun hazır etkinlik } \\
\text { bulmada zorlanma }\end{array}$ & 15 & $\begin{array}{l}\text { Ö1,3,5,6,7,11,13,14,15,16,20,21,24 } \\
, 25,29\end{array}$ \\
\hline & $\begin{array}{l}\text { Yaş grubuna uygun etkinlik oluşturmada } \\
\text { zorlanma }\end{array}$ & 7 & Ö1,5,11,16,20,21,25 \\
\hline & $\begin{array}{l}\text { Etkinliğe uygun bir hikaye bulma, oluşturmada } \\
\text { zorlanma }\end{array}$ & 6 & Ö3,5,11,16,20,24 \\
\hline & Etkinlik planı oluşturmada zorlanma & 6 & $\begin{array}{l}12,16,21,22 \\
24,26\end{array}$ \\
\hline & Kendimi yeterli hissetmeme & 4 & Ö2,5,19,25 \\
\hline & Dikkat çekici, yaratıcı fikirler bulamama & 4 & $8,15,18,26$ \\
\hline & Türkçe kaynak bulmada zorlanma & 1 & Ö7 \\
\hline Uygulama & Materyali yapmada zorlanma & 4 & Ö6,20,23,29 \\
\hline
\end{tabular}


aşaması

Dayanıklı ve işlevsel bir materyal oluşturmada 3 Ö10,14,15

zorlanma

Kısa sürede etkinlik yapmaya çalışma $\quad 1 \quad$ Ö6

Materyalin görünüşünden çok işlevsel olması 1 Ö10

gerekliliği

Tablo 2'de görüldüğü gibi, öğrencilerin verdiği yanıtlar 2 temada gruplandırılmıştır. Bunlar; planlama aşaması ve uygulama aşamasıdır. Planlama aşamasında 16 öğrenci "STEM eğitimi hakkında yeterli bilgiye sahip olmama”, "disiplinler arasında ilişki kuramama”, 15 öğrenci ise "yaş grubuna ve gelişimine uygun etkinlik bulmada zorlanma" olarak düşüncelerini ifade etmektedir. Uygulama aşamasında ise 4 öğrenci "materyali yapmada zorlanma", 3 öğrenci "dayanıklı ve işlevsel bir materyal oluşturmada zorlanma" şeklinde görüş bildirmektedir. Bu ifadelerin dışında öğretmenler tarafından belirtilen farklı görüşlere de rastlamak mümkündür. Öğrencilerin görüşleri aşağıda sunulmuştur:

Ö1: "Stem ĕgitimi ile ilgili daha önce yeterli bilgi sahibi almadığım için çocukların aynı anda fen,matematik, bilim, mühendislik konusu kapsamında plan yapmada zorlandım."

Ö11: "Çocuklara uygun ,çocukların dikkatini çekebilecek konu bulmakta zorlandım."

Ö14: “Aslında STEM temelli etkinlikler planlarken tek zorlandığım kısım; yapılan çalışmaların hedef kitleye uygunluğu(çocukların yaş ve gelişim seviyelerine dikkat ederek bu plan ve etkinlikleri yapmaya ilke edindim".

Ö29: “Anlatacă̆ım konunun materyale uyarlamada biraz zorlandım."

Tablo 3

Öğrencilerin Kendilerini STEM Etkinlikleri Planlama Konusunda Yeterli Hissedip Hissetmedikleri ile Illgili Görüşleri

\begin{tabular}{|c|c|c|c|}
\hline Tema & Alt temalar & $\mathbf{f}$ & Kodlar \\
\hline \multirow[t]{11}{*}{ Yeterli hissediyorum } & Yeterli alan bilgisine sahip olma & 10 & Ö1,7,10,14,16,18,20,23,24,27 \\
\hline & $\begin{array}{l}\text { Planlama konusunda yeterliliği sahip } \\
\text { olma }\end{array}$ & 10 & Ö7,12,14,16,17,20,23,24,27,28 \\
\hline & $\begin{array}{l}\text { Çocuklarla yaparak-yaşayarak } \\
\text { öŏrenmede destek olma }\end{array}$ & 8 & Ö1,7,11,12,20,24,26,27 \\
\hline & $\begin{array}{l}\text { Çocukların yaratıcılığına uygun } \\
\text { etkinlik tasarlamada }\end{array}$ & 8 & Ö1,11,12,17,20,24,26,27 \\
\hline & Uygulama konusunda yeterli olma & 7 & Ö12,13,16,17,26,27,28 \\
\hline & Çocuklara katkısını fark etme & 7 & Ö1,7,10,12,20,24,26 \\
\hline & Disiplinler arası ilişki kurabilme & 5 & Ö7,16,20,24,27 \\
\hline & Çocukların kısıtlanmaması gerektiği & 5 & Ö1,16,20,24,27 \\
\hline & $\begin{array}{l}\text { konusunda } \quad \text { gerekli } \quad \text { yaklaşımları } \\
\text { uygulama }\end{array}$ & & \\
\hline & $\begin{array}{l}\text { Yeteri kadar STEM etkinliği planlama } \\
\text { ve uygulama }\end{array}$ & 5 & Ö10,12,20,21,23 \\
\hline & $\begin{array}{l}\text { Daha fazla plan ve uygulama yapmaya } \\
\text { ihtiyaç duyma }\end{array}$ & 9 & Ö6,9,11,15,18,21,25,26,28 \\
\hline \multirow[t]{5}{*}{ Yeterli hissetmiyorum } & Yeterli alan bilgisine sahip olmama & 7 & Ö1,3,4,5,6,13,15 \\
\hline & $\begin{array}{l}\text { Planlama konusunda yeterli yeterliliği } \\
\text { sahip olmama }\end{array}$ & 6 & Ö3,4,6,11,18,21 \\
\hline & $\begin{array}{l}\text { Disiplinler arası ilişki kurmada zorluk } \\
\text { yaşama }\end{array}$ & 3 & Ö4,19,21 \\
\hline & $\begin{array}{l}\text { Ortaöğretimde ön koşul öğrenmelerin } \\
\text { gerçekleşmemesi }\end{array}$ & 3 & Ö6,21,26 \\
\hline & $\begin{array}{lcr}\begin{array}{l}\text { Çocuğun } \\
\text { etkinlik }\end{array} & \text { gelişimine } & \text { uygun olacak } \\
\text { yetersizlik } & & \text { konusundama }\end{array}$ & 1 & Ö3, \\
\hline
\end{tabular}




$\begin{array}{lcccc}\begin{array}{l}\text { Kısmen } \\ \text { hissediyorum }\end{array} \quad \text { yeterli } & \begin{array}{l}\text { Materyal hazırlamada güçlük yaşama } \\ \text { Çocuklarla birebir uygulama yapmamış }\end{array} & \text { Ö5,8,11,19 } \\ & \begin{array}{l}\text { olmak } \\ \text { Stajda böyle bir uygulama } \\ \text { gözlemlememiş olma }\end{array} & \text { Ö5,11,19,25 }\end{array}$

Tablo 3'e göre, öğrencilerin yanıtları 3 temaya ayrılmıştır. Bunlar, yeterli hissediyorum, yeterli hissetmiyorum ve kısmen yeterli hissediyorum şeklindedir. Yeterli hissediyorum temasında 10 'ar öğrenci "Yeterli alan bilgisine sahip olma", Planlama konusunda yeterliliği sahip olma", 8'er öğrenci "çocuklarla yaparak-yaşayarak öğrenmede destek olma”, "çocukların yaratıcıllğına uygun etkinlik tasarlama" da kendilerini yeterli hissettiklerini ifade etmektedir. Yeterli hissetmiyorum temasında, 9 öğrenci "daha fazla plan ve uygulama yapmaya ihtiyaç duyma", 7 öğrenci "yeterli alan bilgisine sahip olmama", 6 öğrenci ise "planlama konusunda yeterli yeterliliği sahip olmama" konusunda kendini yetersiz gördügünü belirtmiştir. Kısmen yeterli hissediyorum temasında, 6 öğrenci "daha çok araştırma yapmaya ihtiyaç duyma" ve 4'er öğrenci "çocuklarla birebir uygulama yapmamış olmak" ve "stajda böyle bir uygulama gözlemlememiş olma" da kendilerini kısmen yetersiz gördüklerini söylemişlerdir. Bu görüşlerin dışında öğretmenler tarafından belirtilen farklı görüşler de bulunmaktadır. Öğrencilerin görüşleri aşağıda sunulmuştur:

Ö7: “STEM etkinliklerini planlama konusunda kendimi yeterli hissediyorum. Çünkü, bu konuda ön koşul bilgileri öğrendim ve STEM ĕgitiminin önemini anladım."

Ö13: "Yapabilirim, ancak her şeyiyle tamamen yapabilecek kadar yeterli hissetmiyorum. Planlama konusunda kendimi geliştirmem ve araştırmacı olmam gerekiyor. Ancak derste yaptı̆̆ımız etkinlikler sayesinde uygulama aşamasında bir problem yaşayacă̆ımı düşünmüyorum.

Ö19: "Daha önce STEM eğitimi hakkında hiçbir bilgim yoktu. Matematik, mühendislik, teknoloji ve fizik, kimya gibi konularda dahil bilim konusunda temel kavramlar konusunda yeterli bilgiyi lisede almadığım için zorlandım."

Ö21: "STEM eğitiminin bir dersin içeriğinde yer alan bir bölüm değil, kendi başına bir ders olsaydı kendimi daha yeterli hissederdim."

Tablo 4

STEM Etkinliklerini Uyguladıktan Sonra Bilim, Teknoloji, Mühendislik ve Matematik Alanlarına Yönelik Görüşleri

\begin{tabular}{|c|c|c|c|}
\hline Tema & Alt temalar & $\mathbf{f}$ & Kodlar \\
\hline \multirow[t]{3}{*}{ Bilim alanı } & $\begin{array}{l}\text { Bilim eğitiminin küçük } \\
\text { yaşlarda önemli ve } \\
\text { gerekli olduğu inancına } \\
\text { sahip olma }\end{array}$ & 14 & Ö1,2,6,7,14,15,16,17,18,20,23,26,27,28 \\
\hline & $\begin{array}{l}\text { Deneyler ve gözlemler } \\
\text { ile bilime adım atmayı } \\
\text { kolaylaştırma }\end{array}$ & 10 & Ö1,5,8,10,11,13,16,19,23,28 \\
\hline & $\begin{array}{l}\text { Problem çözme, } \\
\text { yaratıcı düşünce } \\
\text { becerileri geliştirme }\end{array}$ & 5 & Ö9,18,19,24,26 \\
\hline \multirow[t]{2}{*}{ Teknoloji alanı } & $\begin{array}{l}\text { Çocuğa teknoloji doğru } \\
\text { kullanmada rehberlik } \\
\text { etme }\end{array}$ & 16 & Ö1,2,6,7,9,10,11,12,13,14,15,16,19,20,24,27 \\
\hline & $\begin{array}{l}\text { Bilgisayar } \\
\text { yazılımların(robotik } \\
\text { kodlama, yapay zeka) } \\
\text { eğitimde kullanılması } \\
\text { gerekliliği }\end{array}$ & 5 & Ö14,19,23,24,28 \\
\hline $\begin{array}{l}\text { Mühendislik } \\
\text { alanı }\end{array}$ & $\begin{array}{l}\text { Hayattan örnekler ve } \\
\text { yapılan materyaller ile } \\
\text { yaparak-yaşayarak } \\
\text { öğrenilmeyi } \\
\text { kolaylaştırma }\end{array}$ & 16 & Ö2,3,4,5,6,7,8,9,10,11,14,15,18,19,24,28 \\
\hline
\end{tabular}




\begin{tabular}{|c|c|c|c|}
\hline & $\begin{array}{l}\text { Merak duygusu, } \\
\text { problem çözme ve } \\
\text { yaratıcılığını geliștirme }\end{array}$ & 8 & Ö9,13,14,19,20,24,26,27 \\
\hline & $\begin{array}{l}\text { Mühendislik alanının } \\
\text { çocuklara da uygun } \\
\text { olması }\end{array}$ & 4 & Ö14,19,20,25 \\
\hline & $\begin{array}{lr}\text { Blok } & \text { merkezinin } \\
\text { üretkenlik ve } & \text { tasarlama } \\
\text { sürecine } & \text { katkı } \\
\text { sağlaması } & \end{array}$ & 3 & Ö1,10,28 \\
\hline \multirow[t]{4}{*}{$\begin{array}{l}\text { Matematik } \\
\text { alanı }\end{array}$} & $\begin{array}{l}\text { Matematiğin hayatın } \\
\text { her alanında olduğunu }\end{array}$ & 15 & Ö1,2,3,6,7,8,10,11,12,13,14,15,17,21,24 \\
\hline & $\begin{array}{l}\text { Matematiği öğrenmenin } \\
\text { zor bir iş olmadığı }\end{array}$ & 10 & Ö2,Ö3,10,11,12,13,18,19,23,,27 \\
\hline & $\begin{array}{l}\text { Matematiğin eğlenceli } \\
\text { bir uğraş olduğu }\end{array}$ & 8 & Ö10,13,19,20,23,25,26,27 \\
\hline & $\begin{array}{l}\text { Materyallerle } \\
\text { öğrenmeye destek olma }\end{array}$ & 5 & Ö1,6,9,10,25, \\
\hline
\end{tabular}

Tablo 4'e bakıldığında, öğrencilerin yanıtlarının 4 temada gruplandığı görülmektedir. Bunlar; bilim alanı, teknoloji alanı, mühendislik alanı ve fen alanı şeklindedir. Bilim alanında 14 öğrenci "bilim eğitiminin küçük yaşlarda önemli ve gerekli olduğu inancına sahip olma" ve 10 öğrenci "deney ve gözlemler ile bilime adım atmayı kolaylaştırma" yönünde görüş aktarmıştır. Teknoloji alanında 16 öğrenci "çocuğa teknoloji doğru kullanmada rehberlik etme" şeklinde görüşlerini ifade etmiştir. Mühendislik alanı temasında, 16 öğrenci "hayattan örnekler ve yapılan materyaller ile yaparakyaşayarak öğrenilmeyi sağlama" yönünde fikirlerini aktarmıștır. Matematik alanında 15 öğrenci "Matematiğin hayatın her alanında olduğunu", 10 öğrenci ise "matematiği öğrenmenin zor bir iş olmadığı" yönünde bir görüşe sahip olduğunu belirtmiştir. Bu ifadelerin dişında öğretmenler tarafından belirtilen farklı görüşlere de rastlamak mümkündür. Öğrencilerin görüşleri aşağıda sunulmuştur;

Ö2: “Ben matematiğe çok uzak biriydim ve matematiği öğrenmek çok zor diye düşünürken aslında doğru şekilde verildiğinde tüm alanların matematiğin, mühendislik, bilim ve teknolojinin ögrenebileceğini görmüş oldum."

Ö10: "Bilim, matematik ve mühendisliğe ait kavramlar genellikle soyut olarak verilir, ancak mantığını anlamadığımız geçmişten gelen bir korku haline dönüşür. Aslında tüm bu alanlarlarda konuların ne kadar ĕglenceli ve kolay olduğunu fark etmiş oldum."

Ö24: "Teknolojiye genelde zararlı yön olarak bakılmaktadır ama çocukları da bu teknolojiden koparamamaktayız. Bu durumu avantaja çevirerek hayal güçlerini geliştirecek robotik kodlama gibi alanlarda kullandırabiliriz.",

Tablo 5

Öğrencilerin Staj Uygulamalarında STEM Etkinliklerine Yer Verip Vermedikleri Hakkındaki Görüsleri

\begin{tabular}{|c|c|c|c|}
\hline Tema & Alt temalar & $\mathbf{f}$ & Kodlar \\
\hline $\begin{array}{l}\text { Yer } \\
\text { veriyordum }\end{array}$ & $\begin{array}{l}\text { Matematik, mühendisliğin } \\
\text { bütünleştirildiği } \\
\text { etkinlikler planlama }\end{array}$ & 1 & Ö1 \\
\hline \multirow{3}{*}{$\begin{array}{l}\text { Yer } \\
\text { vermiyor- } \\
\text { dum }\end{array}$} & $\begin{array}{l}\text { STEM hakkında bilgi } \\
\text { sahibi olmama }\end{array}$ & 22 & Ö2,3,5,6,7,8,9,10,11,13,14,15,16,17,18,19,20,21,25,26,27,28 \\
\hline & $\begin{array}{l}\text { Staj öğretmeninin STEM } \\
\text { etkinliklerinin çocuklara } \\
\text { uygun olmadığ düşüncesi }\end{array}$ & 4 & Ö12,17,23,24 \\
\hline & $\begin{array}{l}\text { Disiplinler arası bir } \\
\text { yaklasım kullanmama }\end{array}$ & 1 & Ö1 \\
\hline
\end{tabular}


Tablo 5 incelendiğinde, öğrencilerin cevaplarının 2 temada yer veriyorum ve yer vermiyorum verilmiştir. Yer veriyorum temasında 1 öğrencinin "matematik, mühendisliğin bütünleştirildiği etkinlikler planlama" yaptığı görülmektedir. Yer vermiyordum temasında 22 öğrencinin "STEM hakkında bilgi sahibi olmama", 4 öğrencisi ise "staj öğretmeninin STEM etkinliklerinin çocuklara uygun olmadı düşüncesi” şeklinde görüş belirtmiştir. Öğrencilerin görüşleri aşağıda verilmektedir:

Ö13: "Yer vermedim, çünkü staj yaptığım dönemde STEM etkinliklerini bilmiyordum."

Ö23: "Hayır vermiyordum, çünkü yaş grubum küçüktü ve staj öğretmenim bunun küçük çocuklara uygun olmadı̆̆ını söylemişti.”

Tablo 6

Öğrencilerin Bundan Sonra Hazırlayacakları Planlarında STEM Etkinliklerine Yer Verme Konusundaki Görüssleri

\begin{tabular}{llll}
\hline Tema & Alt temalar & f & Kodlar \\
\hline $\begin{array}{l}\text { Yer vermeyi } \\
\text { düşünüyorum }\end{array}$ & Çocukların yaparak-yaşayarak öğrenmelerini & 12 & $1,3,4,5,6,8,10,13,16,24,25,28$ \\
& sağlama & & \\
& 21.yy. becerilerine sahip bireyler yetiştirme & 9 & Ö4,6,7,9,10,14,19,24,28 \\
& $\begin{array}{l}\text { Çocukların hayal gücü, yaratıcılı gücünü } \\
\text { geliştirme }\end{array}$ & Ö1,3,4,11,17,18,24,27 \\
& $\begin{array}{l}\text { İşbirliği ile öğrenmeye teşvik etme } \\
\text { Özgün tasarımlar oluşturmaya destek olma }\end{array}$ & 5 & Ö1,2,12,15,16 \\
& Özgüven gelişimine katk1 sağlama & 2 & Ö1,15,18,27 \\
& & & \\
\hline
\end{tabular}

Tablo 6'da yer alan öğrenci görüşleri yer vermeyi düşünüyorum temasında gösterilmiştir. 12 öğrenci "çocukların yaparak-yaşayarak öğrenmelerini sağlama”, 9 öğrenci "21. yy. becerilerine sahip bireyler yetiştirme" konusunda görüş bildirmiştir. Aşağıda öğrencilerin görüşleri verilmektedir:

Ö1: "Tabiki de düsünüyorum. Çocuğun düşüncelerini hiçbir açıdan klsıtlamayarak özgürce ögrenmesine öncülük ediyor, katkıda bulunuyor. Bunun yanında grup çalışmalart ile işbirlikçi öğrenmeyi destekleyerek, paylaşımcı, girişimci bireyler olmalarını sağllyor."

Ö7: "Elbette bu konuda etkinlik planlamayı ve uygulamayı düşünüyorum. Çünkü yaşadığımız çăgda 21. Yy. becerilerine sahip çocuklar yetiştirmenin en etkili yolu STEM etkinlikleridir,diye düşünüyorum"

Ö16: "STEM etkinlikleri çocuklarl matematik, bilim, teknoloji ve mühendislik alanında geliştirdiği gibi aynı zamanda yaparak-yaşayarak öğrenmeyi sağlayarak kalıcı öğrenme gerçekleştirir."

Tablo 7

Öğrencilerin Gündelik Yaşamla İlgili Olayları Açıklamada STEM Etkinliklerinin Faydası

\begin{tabular}{|c|c|c|c|}
\hline Tema & Alt temalar & f & Kodlar \\
\hline \multirow{5}{*}{$\begin{array}{l}\text { Gündelik } \\
\text { yaşamda } \\
\text { olayları } \\
\text { açıklamada }\end{array}$} & Hayata hazırlaması & 14 & Ö1,3,4,8,10,13,14,16,18,19,20,21,26,28 \\
\hline & Hayatın bir parçası olması & 14 & Ö1,2,3,7,8,10,11,12,14,16,17,19,26,28 \\
\hline & Problem çözme becerisi geliştirme & 14 & Ö6,7,9,14,15,18,19,20,21,23,24,25,26,27 \\
\hline & Farklı bakış açısı geliştirme & 10 & Ö3,4,6,14,15,20,23,24,25,27 \\
\hline & İșbirliği anlayıșını geliștirme & 5 & Ö7,14,25,26,27 \\
\hline
\end{tabular}

Tablo 7'de öğrencilerin görüşleri tek bir tema üzerinde yoğunlaşmıştır. Gündelik yaşamda olayları açıklama temasında 14'er öğrenci STEM etkinliklerinin "hayata hazırlaması", "hayatın bir parçası olması" ve "problem çözme becerisi geliştirme" açısından görüşlerini belirtmiştir. Bu görüşler dışındaki kodlarda tabloda yer almaktadır. Öğrencilerin görüşleri şu şekildedir;

Ö2: "STEM hayatın içindedir. Mesele çocuklar dişarıda elma bahçesine gidip ă̆açları inceleyebilirler. Yere düşen elmalar incelenerek, onların neden yere düştüğü konusunda sohbet 
edilebilir, bu sayede yer çekimini keşfedebilirler. Daha sonra bahçeden topladıkları elmaları bölüp kaç parçaya ayrıldığını söyleyebilirler, sınıfta bunları dijital bir terazi ile tartıp ă̆ırlıklarını hesaplayabilirler."

Ö5: "Çocuklar problemlere çözüm üretmekle beraber sistem tasarlar, ürün geliştirir ya da var olan ürün üzerine eklemeler yaparak geliştirir, yenilikler yapar ve hayatını kolaylaştırır."

Ö27: "Grupla işbirliği içinde uyumlu çalışma ile gündelik yaşamda karşılaşacağl olaylara çözüm bulmada daha yeterli olmasina destek olacaktır."

Tablo 8

Öğrencilerin STEM Etkinlikleri Planlama ve Uygulamada Uygulayıcı ve Öğrenciler Açısından Önerileri

\begin{tabular}{llll}
\hline Tema & Alt temalar & f & Kodlar \\
\hline Uygulayıc1 & Öğrenenin aktif olduğu etkinlik planlama & 15 & Ö1,2,4,6,8,9,11,12,14,18,19,20,21,25, \\
$\begin{array}{l}\text { açısından } \\
\text { öneriler }\end{array}$ & & & 26
\end{tabular}

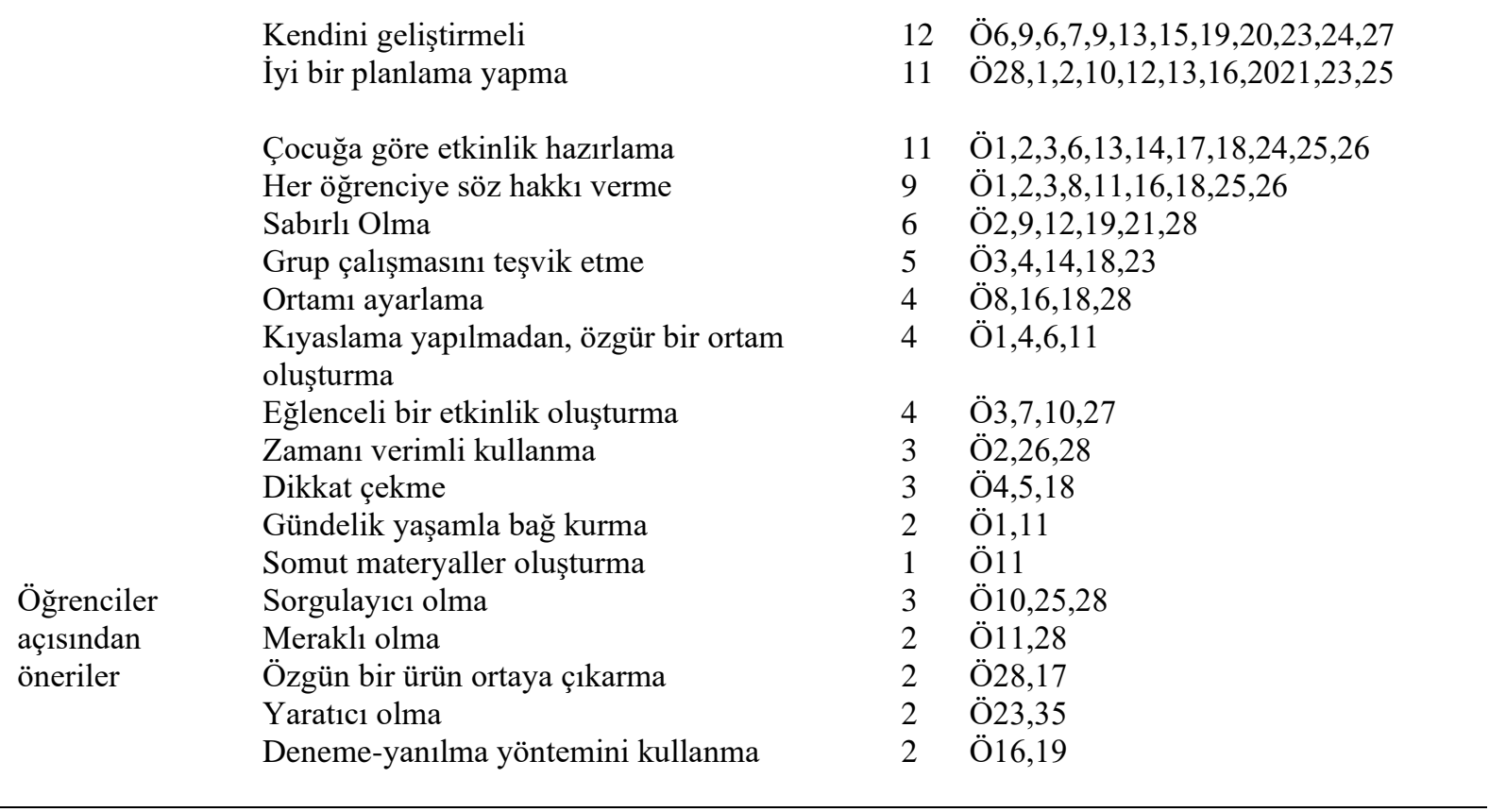

Öğrencilerin verdiği yanıtlara göre Tablo 8'de 2 tema oluşturulmuştur. Bunlar; uygulayıc1 açısından öneriler ve öğrenciler açısından önerilerdir. Uygulayıcı açısından temasında 15 öğrenci "öğrenenin aktif olduğu etkinlik planlama", 11 öğrenci "iyi bir planlama yapma" kodunu oluşturan görüşlerini ifade etmiştir. Öğrenciler açısından temasında, 3 öğrenci "sorgulayacı olma" koduna ait düşünceler belirtmiştir. Bu ifadelerin dışında öğretmenler tarafından belirtilen farklı görüşlere de rastlamak mümkündür. Öğrencilerin görüşleri aşağıda sunulmuştur:

Ö4: “Ö̈̆renciler çözüm yollarl ararken birlikte düşünmenin önemi vurgulanmal,, rekabet ortamının değil grup çallş̧masının teşvik edilmesi gereklidir."

Ö6: "Uygulayılclar sahip oldukları bilgiler ile yetinmeyip, her daim araştırmaya devam etmelidir. Kendini yeterli görmediği bir konuda uygulama yapmadan önce o konuyla ilgili gerekli bilgileri ögrenmelidir."

Ö21: "Uygulayıcı açısından, STEM'in içinde yer alan disiplinleri iyi kavramak ve ögrrenmek gerekir. Etkinlikleri planlarken ve uygularken çocukların aktif olmasına dikkat edilmelidir."

\section{Sonuç, Tartışma ve Öneriler}

$\mathrm{Bu}$ bölümde, çocuk gelişimi programı öğrencileri STEM temelli oluşturulan etkinliklerle ilgili görüşlerini ortaya koymak üzere yapılan bu çalışmadan elde edilen 
bulguların, literatürdeki benzer ve farklı araştırmalar ile karşılaştırarak tartışılması gerçekleştirilmiştir. Araştırmanın sonuçlarına göre, bazı önerilerde bulunulmuştur.

Birinci alt problem doğrultusunda, öğrencilerin STEM etkinliklerini planlamada zorlandıkları sonucuna varılmıştır. $\mathrm{Bu}$ doğrultuda etkinliklere planlama aşamasında öğrencilerin STEM hakkında yeterince bilgi sahibi olmadıklarında, disiplinler arası ilişki kurmada zorlandıkları, yaş grubu ve gelişimine uygun hazır etkinlik bulmada güçlük çektikleri ve uygun bir etkinlik oluşturmada zorlandıkları önemli bir sonuç olarak göze çarpmaktadır. Diğer sonuç ise, STEM etkinlikleri uygulama aşamasında ise materyali yapmada zorlandıklarını, kısa sürede, işlevsel, dayanıklı bir materyal oluşturmada güçlük çektikleri yönündedir.

İkinci alt problem ise öğrencilerin STEM etkinlikleri planlama konusunda kendilerini yeterli görüp görmedikleridir. Öğrencilerin büyük bir kısmı planlama konusunda yeterli oldukları sonucuna ulaşılmıştır. Öğrenciler yeterli alan bilgisine sahip olduklarını, disiplinler arası ilişki kurarak planlama yapma konusunda yeterli bilgi düzeyine ulaştıklarını, çocukların yaratıcılığına uygun, yaparak- yaşayarak öğrenmelerine destek olacak etkinlik tasarlayabilmektedir. Bu sonuçlar STEM eğitim yaklaşımına yönelik gerekli alan bilgisi ve pedagojik bilgiye sahip olmaları için öğretmenlere, uygulayıcılara destek olunması gerektiğini ortaya koyan çalışmalarla benzer bir sonuç ortaya koymaktadır (Altan, Yamak ve Kırıkkaya, 2016, Aronin ve Floyd, 2013; Chesloff, 2013; Çorlu, Capraro ve Capraro, 2014; DeJarnette, 2012; Erdoğan ve Çiftçi, 2017; Gonzalez ve Kuenzi, 2012; Kennedy ve Odell, 2014; Nadelson, Seifert, Moll ve Coats,2012; Stohlmann, Moore ve Roehrig, 2012). STEM etkinliklerini planlamada kendimi yeterli hissetmiyorum şeklinde görüş bildirenler yeterli alan bilgisine sahip olmadıklarını, daha fazla planlama ve uygulama yapmaya ihtiyaçlarının olduklarını hissetmektedirler. Kısmen yeterli hissedenler ise daha çok araştırmaya ihtiyaç duydukları ve staj uygulamalarında böyle bir etkinlik gözlemlememiş olmaları gerektiği sonucuna ulaşılmıştır.

Yıldırım (2016) öğretmenler ile yaptı̆̆ı çalışmada STEM eğitimi konusunda olumlu görüşlere sahip olduklarını fakat bu konuda kendilerini yeterli hissetmediklerini ifade ederek, STEM etkinliklerini uygulayabilmeleri amacıyla ortamın ve imkanların elverişli hale getirilmesi gerektiğini vurgulamıştır. Bu sonuçlar STEM eğitimin yaklaşımına yönelik gerekli alan bilgisi ve pedagojik bilgiye sahip olmaları için öğretmenlere, uygulayıcılara destek olunması gerektiğini ortaya koyan çalışmalarla benzer bir sonuç ortaya koymaktadır (Altan, Yamak ve Kırıkkaya, 2016, Aronin ve Floyd, 2013; Chesloff, 2013; Çorlu, Capraro ve Capraro, 2014; DeJarnette, 2012; Erdoğan ve Çiftçi, 2017; Gonzalez ve Kuenzi, 2012; Kennedy ve Odell, 2014; Nadelson, Seifert, Moll ve Coats,2012; Stohlmann, Moore ve Roehrig, 2012).

Üçüncü alt problemde öğrenciler STEM etkinliklerini uyguladıktan sonra bilim, teknoloji, mühendislik ve matematiğe yönelik görüşlerine ait sonuçları ise, bilim alanı, teknoloji alanı, mühendislik alanı ve matematik alanı olarak ele alınmıştır. Çalışma sonucunda bilim eğitiminin küçük yaşlarda önemli ve gerekli olduğu inancına sahip oldukları, deney ve gözlem ile bilime adım atmayı kolaylaştırdığı görülmektedir. Literatür incelendiğinde, STEM eğitiminin çocukların okul öncesi dönemlerinden başlanarak yürütülmesinin önemi üzerinde duran benzer çalışmalara da rastlanmaktadır (Katz, 2010; Soylu, 2016; Uğraş,2017; Yıldırım ve Selvi,2015;). Çocuğa teknoloji doğru kullanmada rehberlik edilmesi gereklidir ve bilgisayar yazılımlarının (robotik kodlama, yapay zekâ) eğitimde kullanılması önemlidir. Milli Eğitim Bakanlığı (2016), STEM eğitimi raporuna göre iletişim ve işbirliği, liderlik, 
girişimcilik ve eleştirel düşünme becerilerine büyük önem verildiği görülmektedir, bunun yanı sıra küresel anlamda şirketlerin başarısı, ağırlıklı olarak yaratıcı, çeşitli ve eleştirel düşünme becerilerine ve girişimci ruha sahip bireyler ile işbirliği içinde çalışan ve yenilikçi düşünen bireylerle mümkün olacağı belirtilmektedir. Bu noktada okul öncesi dönemden itibaren STEM temelli etkinliklerin yapılması gelecekte bu alanlarda donanımlı bireylerin yetişmesine katkı sağlayacaktır. Mühendislik alanında hayattan örnekler ve yapılan materyaller ile yaparak yaşayarak öğrenmeyi sağladığı önemli bir sonuçtur. Şahin, Ayar ve Adıgüzel,(2014), dünyada STEM alanlarının meslek edinme ve günlük yaşamla ilişkilendirilerek farkındalığın geliştirilmesi mühim olduğunu ifade etmiştir. Bunun yanında problem çözme becerisi ve yaratıcılığ 1 geliştirmede yardımcı olduğu sonucuna varılmıştır. Benzer şekilde Sungur Gül ve Marulcu (2014) yaptıkları çalışmada, öğretmen ve öğretmen adaylarının STEM temelli çalışmaların bilimsel süreç becerilerin de ilerleme sağlayacağını savunmaktadırlar. Çalışmada matematik alanına yönelik sonuçlar ise, matematiğin hayatın her alanında olduğunu ve matematiğin zor bir uğraş olmadığı görüşüne sahip oldukları görülmektedir. Bu sonuç, Darling-Hammond ve Bransford'un (2005), ders içeriği olarak fen ve matematikle ilgili temel bilgilere sahip olan öğretmen adaylarının bu bilgileri öğretmeyi daha kolay bir şekilde yaptıkları şeklindeki ifadeleriyle tutarlıdır.

Çalışmanın dördüncü alt probleminde öğrencilerin STEM etkinlikleri uyguladıktan önce ve uyguladıktan sonra okul öncesi dönemdeki çocuklara yönelik staj uygulamalarında bu etkinliklere yer verme hakkında görüşleri incelenerek çalışmaya ait bazı sonuçlara ulaşılmıştır. Öğrencilerin daha önce yaptıkları staj uygulamalarında büyük çoğunlukla STEM etkinliklerine yer vermediği görülmektedir. Bunun nedeni olarak, STEM hakkında bilgi sahibi olmamalarını ve staj uygulamalarında öğretmenlerin STEM etkinliklerinin okul öncesi döneme uygun olmadığını düşünmeleridir. Ancak STEM etkinliklerini planlayıp, uyguladıktan sonra öğrencilerin tamamı etkinliklerde yer vereceklerini söylemişlerdir. Sonuçlardan anlaşılacağı üzere, Fishbein ve Ajzen (1975) ve Turan'in (2011) da çalışmalarında görüldüğü gibi birey eğer bir davranışa yönelik olumlu tutuma sahipse davranış1 gösterme eğilim de o denli güçlü olacaktır.

Beşinci alt probleme ait sonuçlar ise, öğrencilerin gündelik yaşamla ilgili olayları açıklamada STEM etkinliklerinin problem çözme becerilerini geliştirme, hayatın bir parçası olma, farklı bakış açıları geliştirme, hayata hazırlama ve işbirliği anlayışını geliştirme açısından yararlı olduklarını düşündükleri anlaşılmaktadır. Bu sonuç, Şahin, Ayar ve Adıgüzel (2014) ve Sungur Gül ve Marulcu'nun (2014) yaptıkları çalışmaların sonuçlarıyla benzerlik göstermiştir. Yine STEM yaklaşımının, bilimsel düşünme becerilerini geliştirme de önemli bir yeri olduğu görülmektedir (Strong, 2013; Zorlu ve Zorlu, 2017).

Son alt problemde ise ögrrencilerin STEM etkinliklerini planlama ve uygulamalardan sonra uygulayıcı ve öğrencilere önerileri incelenerek, bazı sonuçlar elde edilmiştir. $\mathrm{Bu}$ sonuçlar, uygulayıcılar için çocuğa göre etkinlik hazırlanması gerektiği, öğrenenin aktif olacağı etkinlik ortamı yaratılması şeklindedir. Öğrenciler açısından ise öğrencilerin sorgulayıcı ve yaratıcı bireyler olmaları gerektiğini ifade ettikleri sonucuna ulaşılmıştır.

Tüm bu sonuçlar doğrultusunda aşağıdaki önerilere gidilmiştir.

1. Bu çalışma 2020-2021 Bahar yarıyılında okul öncesi döneme yönelik STEM eğitimi alan ve derslerinde STEM etkinlikleri uygulayan öğrenciler ile gerçekleştirilmiştir. STEM eğitimiyle ilgili yapılacak çalışmalar farklı sınıf düzeylerinde 
gerçekleştirilebilir. Bunun yanı sıra okul öncesi öğretmenliği ve çocuk gelişimi lisans programlarında da yapılabilir.

2. STEM eğitimi ve etkinliklerinin bir dersin içeriğinde değil öğrencilere zorunlu bir ders olarak programda teorik ve uygulamaya dayalı bir şekilde yer alması uygundur.

3. STEM etkinliklerini gerçekleştirebilmek için okulda buna uygun bir ortam hazırlanması önemlidir.

4. Derste hazırlanan etkinlik planlarının kurumlarla işbirliği yapılarak, bir okul öncesi eğitim kurumunda da öğrencilerin çocuklarla etkileşimli olarak uygulama yapmalarına imkan sağlanmalıdır.

\section{Yazarların Katkı Oranı}

Çalışma tek yazarlı olduğundan dolayı yazarın katkı oranı \%100’dür.

\section{Çıkar Çatışması}

Çıkar çatışması teşkil edebilecek herhangi bir durum yoktur.

\section{Kaynaklar}

Aktaş Arnas, Y. (2003). Küçük bir bilim adamı yetiştirmenin ilk adımları. Çocuk ve Aile, Ekim, 42-46.

Allen, A. (2016). Don't fear STEM-you already teach it. School Age/After School Exchange. September/October 56-59.

Altan, E. B., Yamak, H. ve Kırıkkaya, E. B. (2016). Hizmetöncesi öğretmen eğitiminde FeTeMM eğitimi uygulamaları: Tasarım temelli fen eğitimi. Trakya Üniversitesi Ĕgitim Fakültesi Dergisi, 6(2), 212-232.

Aronin, S. ve Floyd K.K. (2013).Using an iPad in inclusive preschool classrooms to introduce STEM concepts. Teaching Exceptional Children 45(4): 34-39.

Bybee, R.W.(2010). Advancing STEM Education: A 2020 Vision. Technology and Engineering Teacher, 70(1), 30-35.

Chesloff, J.D, (2013). Why STEM education must start in early childhood. Education Week, 32(23): $27-32$.

Corlu, M. S., Capraro, R. M., \& Capraro, M. M. (2014). Introducing STEM education: Implications for educating our teachers in the age of innovation. Education and Science, 39(171), 74-85

Creswell, J. W. (2009). Research design: Qualitative, quantitative, and mixed methods approaches (3rd ed.). Sage Publications, Inc.

Çepni, S. (2018). Kuramdan Uygulamaya STEM Eğitimi (2. Bask1). Ankara: Pegem Akademi Yayınları.

Çınar, S., Pırasa, N., Uzun, N., ve Erenler, S. (2016). The effect of STEM education on pre-service science teachers' perception of interdisciplinary education. Journal of Turkish Science Education, 13 (Special Issue), 118-142. doi: 10.12973/tused.10175a

Darling-Hammond, L., \& Bransford, J. (Eds.). (2005). Preparing teachers for a changing world: What teachers should learn and be able to do. Jossey-Bass. 
Dejarnette, N.K. (2012). America's children: providing early exposure to STEM (Science, Technology, Engineering and Math) initiatives. Education, 133(1), 77-84.

Erdoğan, İ. \& Çiftçi, A. (2017). Investigating the Views of Pre-service Science Teachers on STEM Education Practices. International Journal of Environmental and Science Education, 12 (5), 1055-1065.

Fishbein, M., Ajzen, I., (1975), Belief, Attitude, Intention and Behavior: An Introduction to Theory and Research, Reading. MA: Addison-Wesley.

Gonzalez, H. B., \& Kuenzi, J. J. (2012). Science, technology, engineering, and mathematics (STEM) education: A primer. Congressional Research Service, Library of Congress.

Günüç, S , Odabaşı, H , Kuzu, A . (2013). 21. Yüzyıl Öğrenci Özelliklerinin Öğretmen Adayları Tarafindan Tanımlanması: Bir Twitter Uygulaması / The Defining Characterıstıcs of Students of The 21st Century By Student Teachers: A Twitter Activity . Eğitimde Kuram ve Uygulama, 9(4), 436-455. https://dergipark.org.tr/tr/pub/eku/issue/5458/73999 adresinden 22.04.2021 tarihinde edinilmiştir.

Haciömeroğlu, G. \& Bulur, A.S.(2016). Entegre FETEMM Öğretimi Yönelim Ölçeği Türkçe Formunun Geçerlik ve Güvenirlik Çalışması. Eğitimde Kuram ve Uygulama, 12(3), 654-669.

Karasar, N. (2016). Bilimsel Araştırma Yöntemi. Ankara: Nobel Yayıncılık.

Katz,L.G.(2010). STEM in the early years. Retrieved from http://ecrp.uiuc.edu/beyond/seed/katz.html in 05.01.2021.

Kennedy, T. Ve Odell, M. (2014). Engaging students in STEM education. Science Education International, 25(3), 246-258

Korkmaz, Ö. ve Buyruk, B. (2016). Öğrencilerin fen ve teknolojiye dönük kavramları günlük hayatla ilişkilendirme durumları. Ondokuz Mayıs Üniversitesi Eğitim Fakültesi Dergisi, 35(1), 159172.

Küçükturan, G. (2005). Okul ve aile eğitimi. Ankara: SMG Yayıncılık.

Marulcu, İ., ve Sungur, K. (2012). Fen bilgisi öğretmen adaylarının mühendis ve mühendislik algılarının ve yöntem olarak mühendislik-dizayna bakış açılarının incelenmesi. Afyon Kocatepe Üniversitesi Fen Bilimleri Dergisi, 12(2012), 13-23.

Milli Eğitim Bakanlığı. (2013). Okul öncesi Eğitimi Programı. Ankara: MEB Yayınları.

Milli Eğitim Bakanlığı. (2016). STEM eğitimi raporu. Ankara: Yenilik ve Eğitim Teknolojileri Genel Müdürlüğü.

Meng, C. C., Idris, N. ve Eu, L. K. (2014). Secondary Students' Perceptions of Assessments in Science, Technology, Engineering, and Mathematics (STEM). Eurasia Journal of Mathematics, Science \& Technology Education, 10(3), 219-227.

Miles, M.B. ve Huberman, A.M. (1994). Qualitative Data Analysis (2nd edition). Thousand Oaks, CA: Sage Publications.

Moomaw, S. (2013). Teaching STEM in The Early Years: Activities for Integrating Science, Technology,Engineering, and Mathematics. St Paul MN: Redleaf Press. 
Nadelson, L. S., Seifert, A., Moll, A.J. ve Coats, B. (2012). i-STEM summer institute: an integrated approach to teacher professional development in STEM. Journal of STEM Education: Innovations and Research, v13 n2, p69-83

National Research Council., (2011). Successful K-12 STEM education: Identifying effective approaches in science, technology, engineering, and mathematics. committee on highly successful science programs for K-12 science education. Board on Science Education and Board on Testing and Assessment, Division of Behavioral and Social Sciences and Education. Washington, DC: The National Academies Press.

National Science Teacher Association. (2014). Early Childhood Science Education. Arlington, VA: NSTA. Retrieved from http://www.nsta.org/about/positions/earlychildhood.aspx

Nesbitt, B. J. (2013). Up for the challenge NDPC/N QUARTERLY Newsletters, 24(1). Rincon, B. E., ve George-Jackson, C. E. (2014). STEM intervention programs: funding practicesand challenges. Studies in Higher Education,5079(May),1-16.

Partnership for 21st Century Skills, (2009). A Framework for Twenty-First Century Learning. Recieved from http://www.p21.org/ in 23.02.2021.

Rogers, C., ve Portsmore, M. (2004). Bringing engineering to elementary school. Journal of STEM Education: Innovations and Research, 5(3-4),17-28.

Sanders, M. (2009). STEM, STEM Education, Stemmania. The Technology Teacher, 68 (4),20-26.

Soylu, S. (2016). STEM Education in early childhood in Turkey. Journal of Educational and Instructional Studies in the World, 6, 38-47.

Stohlmann, M., Moore, T. J., ve Roehrig, G. H. (2012). Considerations for teaching integrated STEM education. Journal of Pre-College Engineering Education Research (J-PEER), 2(1), 28-34.

Strong, M. G. (2013). Developing elementary math and science process skills through engineering design instruction. Hofstra University.

Sungur Gül, K. ve Marulcu, İ. (2014). Yöntem olarak mühendislik-dizayna ve ders materyali olarak legolara öğretmen ile öğretmen adaylarının bakış açılarının incelenmesi. International Periodical for The Languages, Literature and History of Turkish or Turkic, 9(2), 761-786.

Şahin, A., Ayar, M. C. \& Adıgüzel, T. (2014). Fen, teknoloji, mühendislik ve matematik içerikli okul sonras1 etkinlikler ve öğrenciler üzerindeki etkileri. Kuram ve Uygulamada Ĕgitim Bilimleri,14 (1), 1-26.

Teo, T. W., ve Ke, K. J. (2014). Challenges in STEM Teaching: Implication for Preservice and Inservice Teacher Education Program. Theory Into Practice, 53(1), 18-24. http://doi.org/10.1080/00405841.2014.862116

Tezel, Ö. ve Yaman, H. (2017). Fetemm Eğitimine Yönelik Türkiye'de Yapılan Çalışmalardan Bir Derleme. Ĕgitim ve Ögretim Araştırmaları Dergisi, 6(1), 2146-9199.

Thomas, T. A., (2014). Elementary teachers' receptivity to integrated science, technology, engineering, and mathematics (STEM) education in the elementary grades. (Doctoral dissertation). Retrieved from Proquest (3625770) in 15.02.2021. 
Torres-Crospe, M. N., Kraatz, K. ve Pallansch, L. (2014). From fearing STEM to playing with it: The natural integration of STEM into the preschool classroom. SRATE Journal, 23(2), 8-16.

Turan, A. H. (2011). Internet Alışverişi Tüketici Davranışını Belirleyen Etmenler: Planlı Davranış Teorisi (TPB) ile Ampirik Bir Test. Doğuş Üniversitesi Dergisi, 12(1), 128-143

Uğraş, M. (2017). Okul öncesi öğretmenlerinin STEM uygulamalarına yönelik görüşleri. Eğitimde Yeni Yaklaşımlar, 1(1), 39-54.

Uğraş, M., ve Genç, Z. (2018). Proschool teacher candidates' views about STEM education. Bartın Üniversitesi Ë̆itim Fakültesi Dergisi, 7(2), 724-744.

Van Manen, M. (2007). Phenomenology of Practice. Phenomenology \& Practice, 1, 11-30.

Wang, H. (2012). A new era of science education: science teachers' perceptions and classroom practices of science, technology, engineering and mathematics (STEM) integration. (Doctoral Dissertation) Minnesota Univercity: United States.

Yıldırım, B., (2016). 7. Sinıf fen bilimleri dersine entegre edilmiş fen teknoloji mühendislik matematik (STEM) uygulamaları ve tam ögrenmenin etkilerinin incelenmesi. Yayınlanmamış Doktora Tezi. Ankara: Gazi Üniversitesi.

Yıldırım, A. ve Şimşek, H. (2003). Sosyal Bilimlerde Nitel Araştırma Yöntemleri. Ankara: Seçkin Yayınları.

Yıldırım, B. ve Altun,Y. (2014).STEM Eğitimi Üzerine Derleme Çalışması: Fen Bilimleri Alanında Örnek Ders Uygulanmaları. M. Riedler et al. (Ed.). VI. International Congress of Education Research. Hacettepe Üniversitesi: Ankara .

Yildırım, B. ve Selvi, M. (2015). Adaptation of STEM attitude scale to Turkish. Turkish Studies, 10(3), 1107-1120.

Yıldırım, B. ve Türk, C. (2018). Sınıf Öğretmeni Adaylarının STEM Eğitimine Yönelik Görüşleri: Uygulamalı Bir Çalışma. Trakya Üniversitesi Eğitim Fakültesi Dergisi, 8(2), 195-213.

Zorlu, F., ve Zorlu, Y. (2017). Comparison of Science Process Skills with STEM Career Interests of Middle School Students. Universal Journal of Educational Research, 5(12). 


\section{Extended Abstract}

\section{Introduction}

The use of STEM as a term or concept in education was first expressed in 2001 by Judith A. Ramaley, the director of The National Science Foundation, and spread in a short time (Yildirim \& Altun, 2014). STEM education approach is a holistic field of study that builds bridges between the fields of science and mathematics, technology and mathematics, and ensures interdisciplinary integration, and is a holistic approach that includes the integration of disciplines (Bybee, 2010, Meng, Idris, \& Eu, 2014).

When the literature is examined, there is no study on STEM in the associate degree child development program. However, considering that students trained in this field do internships and after graduation they work as teachers and assistant teachers in private nurseries and day care centers, it is seen that there is a deficiency in this field. The studies were generally carried out with prospective teachers in undergraduate programs. There is no similar study on STEM activities in the associate degree program. Nadelson, Seifert, Moll, and Coats (2012) suggested that pre-service teachers who have content knowledge and subject-area knowledge are comfortable during their teaching activities and their positive attitudes towards STEM fields positively affect their self-efficacy perceptions for STEM teaching, on the other hand, they use a questioning understanding positively. stated that it affected.

With this study, it is aimed to reveal the views of child development program students about STEM-based activities. As a result of the applications made with the students, it was aimed to obtain in-depth information about their real thoughts, ideas and feelings by making one-to-one interviews. Since students in the child development program will work with preschool children after graduation, it is important to reveal their views on STEM activities. No study has been found on this subject with child development students. It is thought that it will contribute to the field with this feature.

\section{Method of Research}

This study was carried out with a phenomenological pattern. In this study, students of the child development program are put forward their thoughts about these activities after applying STEM-based activities within the scope of Science and Technology in Children course. Interview method, one of the qualitative research methods, was used in order to reveal their thoughts about STEM activities in depth, and data were collected with semi-structured interview questions. In the study group, there are 28 students, 27 girls and 1 boy, aged between 18-22, studying in the 2nd year of the Child Development program of a state university in the Marmara Region. The students in the study group were determined by purposeful sampling method. As a data collection tool, a 7-question semi-structured interview form created by the researcher was used. The interviews lasted between 30-35 minutes. Instead of the names of the students, coding was made as T1, T2, T3,.., T28. In the formation of conceptual categories, the findings of both researchers were compared and then the consistency level was tried to be determined. Miles and Huberman's (1994, p. 64) formula (Reliability $=$ consensus $/$ consensus + disagreement X 100) was found to be $94 \%$. According to Miles and Huberman (1994), the consistency of $88 \%$ and more in the comparison of the classifications made by the two researchers increases the reliability of the study. 


\section{Findings}

In the findings of the study, it is seen that the students mostly stated that they had difficulty in establishing interdisciplinary relationships and designing activities suitable for the age group because they did not have information about STEM education. They stated that they mostly felt competent in event planning, but they needed more planning and implementation. After applying STEM activities, they stated that they have the belief that science is important and teaching is necessary at an early age for the fields of science, technology, engineering and mathematics. In addition, they stated that children should be guided in the correct use of technology. It is understood that they will make learning easier by giving examples from life in the field of engineering, and in the field of mathematics, they believe that mathematics is in every field of life and that it is not a difficult occupation. It is seen that they stated that they do not give place in internship practices because they do not have information about STEM activities in general. And it is understood that they are planning to include in their next applications. In explaining the events related to daily life, STEM activities are seen to express that they prepare children for life and improve their problem solving skills. It is understood that they make suggestions for more practitioners in planning and implementing STEM activities.

\section{Conclusion, Discussion and Recommendations}

It has been concluded that most of the students are competent in planning. Students can design activities that will support their learning by doing and experiencing, that they have sufficient knowledge of the field, that they have reached a sufficient level of knowledge about planning by establishing interdisciplinary relationships, and that are suitable for children's creativity. Yildirım (2016), in his study with teachers, stated that they have positive opinions about STEM education, but they do not feel themselves competent in this regard, and emphasized that the environment and facilities should be made suitable for them to apply STEM activities. These results reveal a similar result with the studies revealing that teachers and practitioners should be supported in order to have the necessary field knowledge and pedagogical knowledge for the approach of STEM education (Erdoğan \& Çiftçi, 2017; Altan, Yamak, \& Kırıkkaya, 2016, Çorlu, Capraro, \& Capraro, 2014; Kennedy \& Odell, 2014; Aronin \& Floyd, 2013; Chesloff, 2013; DeJarnette, 2012; Gonzalez \& Kuenzi, 2012; Nadelson, Seifert, Moll \& Coats, 2012; Stohlmann, Moore \& Roehrig, 2012).

As a result of the study, it is seen that they have the belief that science education is important and necessary at an early age, and it makes it easier to step into science with experimentation and observation. When the literature is examined, there are similar studies that emphasize the importance of conducting STEM education starting from the preschool period of children (Katz, 2010; Yıldırım \& Selvi, 2015; Soylu, 2016, Uğraş, 2017).

These results are in the form of creating an activity environment in which the learner will be active, and the activities should be prepared for the practitioners. In terms of students, it was concluded that students stated that they should be questioning and creative individuals. $t$ is understood that STEM activities are beneficial in terms of developing problem solving skills, being a part of life, developing different perspectives, preparing for life, and developing cooperation. This result is similar to the results of the studies conducted by Şahin (2014) and Sungur Gül and Marulcu (2014). It is also seen that the STEM approach has an important place in developing scientific thinking skills (Strong, 2013; Zorlu \& Zorlu, 2017).

In line with all these results, the following recommendations have been made.

1. This study was carried out with students who received STEM education for the pre-school period and applied STEM activities in their classes in the 2020-2021 Spring semester. Studies on STEM education can be carried out at different grade 
levels. In addition, it can be done in preschool teaching and child development undergraduate programs.

2. It is appropriate to include STEM education and activities not in the content of a course but as a compulsory course in the program based on theory and practice.

3. In order to perform STEM activities, it is important to prepare an environment suitable for this at school.

4. In cooperation with institutions, the activity plans prepared in the course should be made possible for students to practice interactively with children in a pre-school education institution. 